\title{
Pollicipes caboverdensis sp. nov. (Crustacea: Cirripedia: Scalpelliformes), an intertidal barnacle from the Cape Verde Islands
}

\author{
JOANA N. FERNANDES ${ }^{1,2,3}$, TERESA CRUZ ${ }^{1,2} \&$ ROBERT VAN SYOC ${ }^{4}$ \\ ${ }^{1}$ Laboratório de Ciências do Mar, Universidade de Évora, Apartado 190, 7520-903 Sines, Portugal \\ ${ }^{2}$ Centro de Oceanografia, Faculdade de Ciências da Universidade de Lisboa, Campo Grande, 1749-016 Lisboa, Portugal \\ ${ }^{3}$ Section of Evolution and Ecology, University of California, Davis, CA 95616, USA ${ }^{4}$ Department of Invertebrate Zoology and \\ Geology, California Academy of Sciences, 55 Music Concourse Dr, San Francisco, CA 94118-4599, USA
}

\begin{abstract}
Recently, genetic evidence supported the existence of a new species of the genus Pollicipes from the Cape Verde Islands, previously considered a population of $P$. pollicipes. However, $P$. pollicipes was not sampled at its southern limit of distribution (Dakar, Senegal), which is geographically separated from the Cape Verde Islands by about $500 \mathrm{~km}$. Herein we describe Pollicipes caboverdensis sp. nov. from the Cape Verde Islands and compare its morphology with the other three species of Pollicipes: P. pollicipes, P. elegans and P. polymerus. Pollicipes pollicipes was sampled at both the middle (Portugal) and southern limit (Dakar, Senegal) of its geographical distribution. The genetic divergence among and within these two regions and Cape Verde was calculated through the analysis of partial mtDNA CO1 gene sequences. Pollicipes caboverdensis sp. nov. has a single whorl of capitular plates below the subrostrum, peduncular scales pointing up toward the capitulum and multi-articulate caudal appendages (all characters shared with $P$. pollicipes and $P$. elegans), reddish-orange capitular plates (large specimens), a single rostral median latus between the median latus and the rostrolatus (both characters shared with P. elegans), and uniquely possesses peduncular scales that are approximately the same width as height. The genetic distance between the Cape Verde population and the Senegal and Portugal populations is $13-14 \%$, whilst between Senegal and Portugal it is $<1 \%$.
\end{abstract}

Key words: Pollicipes, new species, morphology, DNA sequences, Cape Verde, Dakar

\section{Introduction}

Until recently, of the six species of stalked barnacles of the genus Pollicipes described in detail by Darwin (1852), only three were recognized as belonging to Pollicipes (Foster 1979; Newman and Killingley 1985; Newman 1987): P. pollicipes (Gmelin, 1790), P. elegans Lesson, 1831 and P. polymerus Sowerby, 1833. The other three species have been assigned to different genera: P. mitella is now Capitulum mitella (Linnaeus, 1758), P. spinosus is now Calantica spinosa (Quoy and Gaimard, 1835), and P. sertus Darwin, 1852 is synonymised with $C$. spinosa (Jennings, 1915).

All Pollicipes species inhabit wave-exposed rocky shores and are mostly intertidal. All species can be an important economic resource, e.g. P. polymerus in Canada (Lessard et al. 2002) and P. pollicipes in the Iberian Peninsula (Molares and Freire 2003; Jacinto et al. 2010).

Pollicipes pollicipes is found in the eastern Atlantic from south-western England (Newman and Killingley 1985) through France, Spain, Portugal and West Africa to Dakar (Senegal, $\approx 15^{\circ} \mathrm{N}$ ), including the Cape Verde Archipelago $\left(\approx 15^{\circ} \mathrm{N}\right.$ to $\left.\approx 17^{\circ} \mathrm{N}\right)$ (Stubbings 1967; Barnes 1996). Pollicipes polymerus and P. elegans are found along the open coast of the eastern Pacific: P. polymerus ranging from southern Alaska to southern Baja California; P. elegans from Baja California to Peru (Newman and Killingley 1985; Barnes 1996).

Morphologically, P. polymerus can be distinguished from P. pollicipes and P. elegans by the existence of: more than one whorl of capitular plates below the sublatera (Darwin 1852; Van Syoc 1995); uni-articulate caudal appendages (Darwin 1852); and peduncular scales pointing outward rather than up toward the 
capitulum (Van Syoc 1995). Darwin (1852) considered that $P$. pollicipes and $P$. elegans were very similar and pointed out that the most striking difference between the species is the reddish-orange of the plates of the capitulum of $P$. elegans compared with the white-gray plates of $P$. pollicipes. Newman (1987) observed that in $P$. elegans the rostrolatus and carinolatus are less separated from the median latus than in P. pollicipes. None of the morphological characters used by Van Syoc (1995) distinguished P. pollicipes from P. elegans.

Recently, genetic studies have shown that a population of Pollicipes from the Cape Verde Islands was highly divergent from European and North African populations of P. pollicipes (Quinteiro et al. 2007), and have supported suggestions that populations of Pollicipes from the Cape Verde Islands belong to a new and undescribed species (Van Syoc et al. 2010). Van Syoc et al. (2010) suggested that this new species from Cape Verde, $P$. pollicipes and P. elegans are the most recently diverged species in the genus, some time after the Eocene/Oligocene boundary radiation of Pollicipes, about 25-34 MYBP, while P. polymerus has emerged at a much earlier time on the north-western margin of the Tethys, what is now the northeastern Pacific, at around 55-65 MYBP.

However, in none of these studies was P. pollicipes sampled at its southern limit, Dakar, Senegal. Its occurrence at Dakar was noted by Sourie (1954) and Stubbings (1967). Dakar is about $500 \mathrm{~km}$ east of the Cape Verde Islands and the closest rocky shore region to the north is Cap Blanc, Mauritania $(\approx 650 \mathrm{~km}$ north of Dakar), with a long stretch of sand in-between. Considering the recent findings of a new species of Pollicipes from Cape Verde (Van Syoc et al. 2010), some doubt can exist regarding the identification of populations from Dakar as P. pollicipes.

The objectives of the present study are to describe Pollicipes caboverdensis sp. nov. and to calculate the genetic divergence between $P$. caboverdensis sp. nov. and $P$. pollicipes populations from both the middle (Portugal) and the southern limit (Dakar) of the latter's geographical range. Additionally, remarks on the habitat, distribution and abundance of $P$. caboverdensis sp. nov. and $P$. pollicipes at Dakar are given.

\section{Material and methods}

Pollicipes caboverdensis sp. nov. was collected at two islands (Santiago and Sal) in the Cape Verde

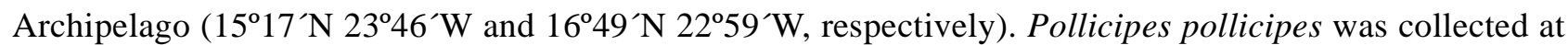
Cabo de Sines, Portugal, (37 $\left.57^{\prime} \mathrm{N} 8^{\circ} 53^{\prime} \mathrm{W}\right)$ and at three different sites in Dakar, Senegal: Yoff $\left(14^{\circ} 45^{\prime} \mathrm{N}\right.$ $\left.17^{\circ} 28^{\top} \mathrm{W}\right)$, in front of the Institut Fondamental d'Afrique Noire Ch. A. Diop (IFAN) $\left(14^{\circ} 41^{\prime} \mathrm{N} 17^{\circ} 28^{\top} \mathrm{W}\right)$ and at Cap Manuel $\left(14^{\circ} 38^{\prime} \mathrm{N} 17^{\circ} 26^{\prime} \mathrm{W}\right)$. Both samplings were carried out in February 2008. Samples of $P$. caboverdensis sp. nov. from São Vicente Island, collected by a local fisherman in 2005, were also used. All material was preserved in $95 \%$ ethanol. Approximately 50 individuals from each region (Portugal, Senegal and Cape Verde) were used for morphological comparisons and 10 individuals from each region were used for DNA sequencing.

Additionally, individuals of P. polymerus collected at British Columbia, Canada, and of P. elegans collected at Baja California, Mexico and at Peru (see reference of species acquisition in Van Syoc 1995) were also used for morphological comparisons.

The following morphological characters were used for species comparisons and diagnosis: number of whorls of capitular plates below the subrostrum (Van Syoc 1995); number of segments of the caudal appendages (Darwin 1852; Van Syoc 1995); orientation of peduncular scales (Van Syoc 1995); colour of capitular plates (Darwin 1852); arrangement of plates on the capitulum; and shape of the peduncular scales.

Rostro-carinal length (RC, distance between rostrum and carina plates) was measured for specimens of $P$. caboverdensis sp. nov. and of $P$. pollicipes. Morphological characters of the peduncle, filamentary appendages and cirri, and the number of segments of the caudal appendages, were analysed using a dissecting microscope. Additionally, the mouth parts, penis and caudal appendages of $P$. caboverdensis $\mathbf{s p}$. nov. were described using a compound microscope.

Total genomic DNA was extracted from barnacle adductor muscle with a Gentra Puregene Tissue Kit (Qiagen). A portion of CO1 gene (mtDNA) was amplified using the primers PPCO1_190: $5^{\prime}$ GGTCAACCCGGAAGATTAATTGG-3'(forward) and PPCO1_JR: 5'- 
CTTTAATACCTGTAGGGACAGCA-3'(reverse) for Pollicipes caboverdensis sp. nov. and PPCO1_1: 5'TAACGGCCCATGCCTTTAT-3' (forward) and PPCO1_1R: 5'-GAAATAAGCCCGGGTGTCTA-3' (reverse) for $P$. pollicipes. All PCR reactions were conducted in $25 \mu \mathrm{L}$ volumes, with $2.5 \mu \mathrm{L}$ of $10 \mathrm{x}$ PCR Buffer (containing $25 \mathrm{mM} \mathrm{MgCl} 2$ ), $2 \mu \mathrm{L}$ of $2 \mathrm{mM}$ dNTP's, $0.75 \mu \mathrm{L}$ of each $10 \mu \mathrm{M}$ primer, $1 \mu \mathrm{L}$ of template DNA, and $0.2 \mu \mathrm{L}$ of HotStarTaq (Qiagen) DNA polymerase. PCR cycles were: initial activation step of 15 $\min$ at $95^{\circ}, 35$ cycles of $30 \mathrm{~s}$ at $94^{\circ}, 30 \mathrm{~s}$ at $56^{\circ}$, and $1 \mathrm{~min}$ at $72^{\circ}$, and a final extension of $10 \mathrm{~min}$ at $72^{\circ}$. PCR products were purified through Exo-SAP method. Sequencing reactions were performed for both forward and reverse strands using BigDye (Applied Biosystems) terminator chemistry, and run on an ABI 3730 (Applied Biosystems) automated DNA sequencer. Complementary strands for each sample were proofread and aligned in Geneious v4.7 (Biomatters). A 660 bp alignment was obtained. Sequences were deposited in Genebank under the accession numbers HM563649-HM563678.

Pairwise genetic distances within and among populations of $P$. pollicipes and $P$. caboverdensis $\mathbf{s p .}$ nov. from the sampled regions were calculated (p-distances) and a neighbour-joining tree was built. Support for nodes was determined by bootstrapping methods (10000 replicates). All analyses were performed in MEGA 4.0.1 (Tamura et al. 2007).

The following abbreviations are used in the text: CASIZ (California Academy of Sciences, San Francisco, USA); MB (Museu Nacional de História Natural, Lisbon, Portugal); MNHN (Muséum national d’Histoire Naturelle, Paris, France); NHM (Natural History Museum, London, UK);

\section{Systematics}

Subclass Cirripedia Burmeister, 1834

Superorder Thoracica Darwin, 1854

Order Scalpelliformes Buckeridge and Newman, 2006

Superfamily Scalpelloidea Pilsbry, 1916

Family Scalpellidae Pilsbry, 1907

Genus Pollicipes Leach, 1817

Pollicipes caboverdensis sp. nov.

(Figs 1-6, Tables 1, 2)

Material examined. Holotype: MB11000930 (24.5 mm RC), Cape Verde, Santiago Island, Punta Preta $\left(15^{\circ} 17^{\prime} \mathrm{N} 23^{\circ} 46^{\prime} \mathrm{W}\right)$, rocky intertidal, collected by hand, Joana Fernandes and Teresa Cruz, 25 February 2008. Paratypes (all specimens with same locality and collection date as holotype): NHM 2009.316-320 (4 specimens; 15.7-22.6 mm RC); MNHN-Ci3198 (4 specimens; 17.4-21.5 mm RC); CASIZ 179504 (9 specimens; 6.9-18.3 mm RC).

Diagnosis. Pollicipes with only one rostral median latus (RML), both in large (RC $>15 \mathrm{~mm}$ ) and very small specimens (RC <3mm) (Figs 1,2); colour of capitular plates reddish-orange in large sized individuals (Fig. 1, 2); peduncular scales about same width as height (Fig. 3).

Description. Capitulum triangular. Paired scuta, paired terga and carina large plates, terga largest. Smaller plates added in whorls below bases of five main plates: rostrum and pairs of median latera [herein we use the nomenclature of Newman (1987); Darwin (1852) used upper latera], carinolatera and rostrolatera most prominent; additionally, subrostrum, subcarina and extra latera, including carinal median latera and diagnostic pair of RML (Fig. 2). Whorl of very small plates below subrostrum. Largest plates of large (RC $>15 \mathrm{~mm})$ specimens reddish-orange. 


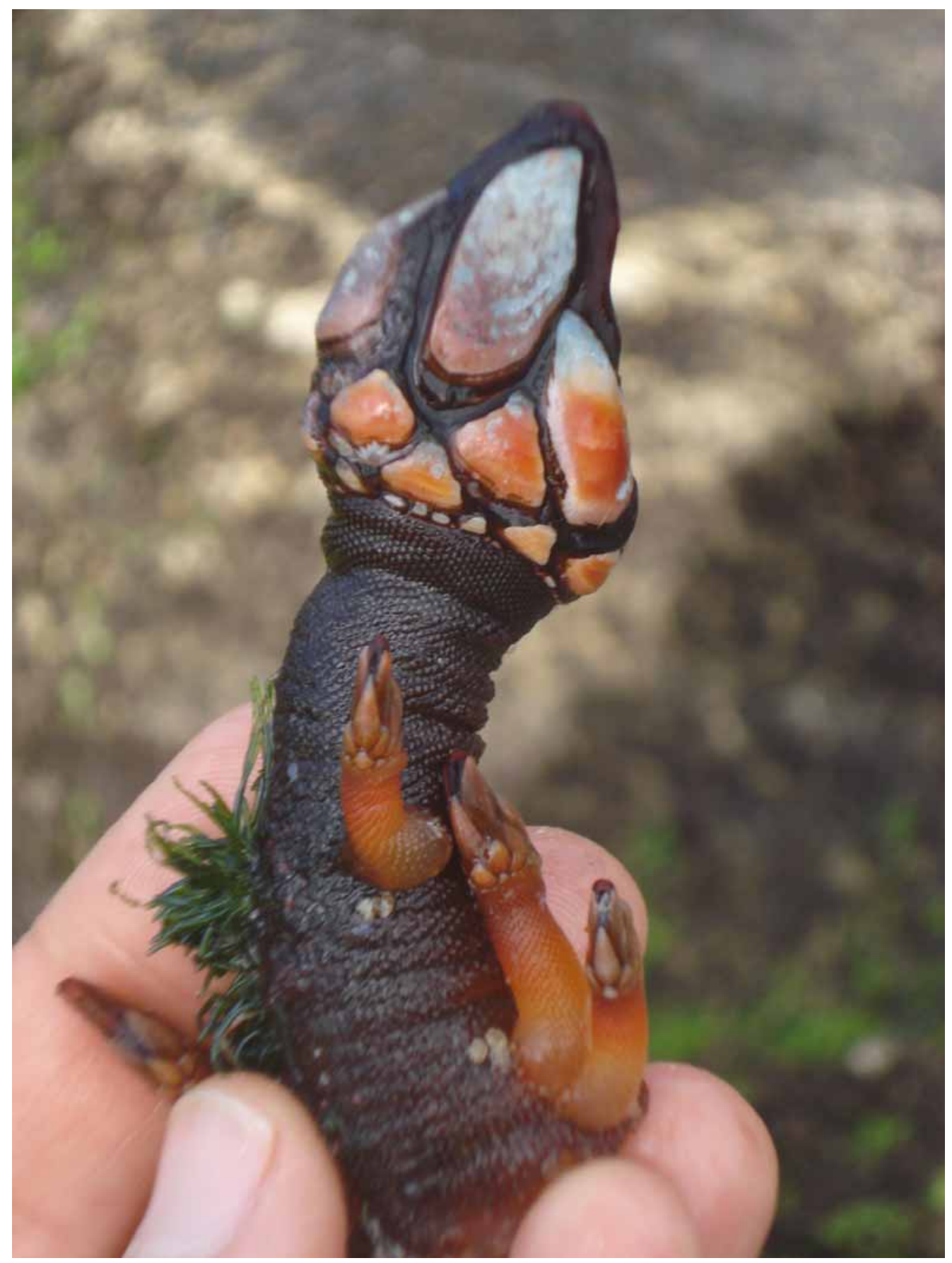

FIGURE 1. Pollicipes caboverdensis sp. nov., Cape Verde Islands. View from the left side.

Peduncle orange-brown, clothed with flexed, square-shaped scales, homogeneous in colour (reddishorange). Peduncular scales as wide or wider than high, overlapping those in row above by about $1 / 2$ scale length.

Prosoma with 15 pairs of filamentary appendages in two longitudinal rows. Thorax with three filaments at base of first pair of cirri (CI), one filament at base of CIV and one at base of CV; several papillae indicating tendency to formation of filaments at bases of CII and CIII; one filament on each side of oral cone.

Labrum bullate, width equaling that of oral cone.

Mandibular palp oval, outer and inner margins thickly clothed with long setae (Fig. 4a).

Mandible with three strong, yellow teeth, first (upper) tooth strongest, notch between first and second more pronounced than that between second and third; tuft of fine setae on upper margin of mandible; lower angle of mandible oval, bearing series of spines (Fig. 4b). 
Maxillule with long, strong spine at upper angle, indistinct notch below with numerous pairs of smaller setae; cutting edge below stepped, with five pairs of longer, stout setae; lower angle stepped, with five pairs of smaller setae (Fig. 4c).

Maxillae wide, lobes subequal, setae long, dense, notch between lobes naked (Fig. 4d).

Six pairs of cirri, first pair much shorter than remainder; number of segments for each cirrus listed in Table 1.
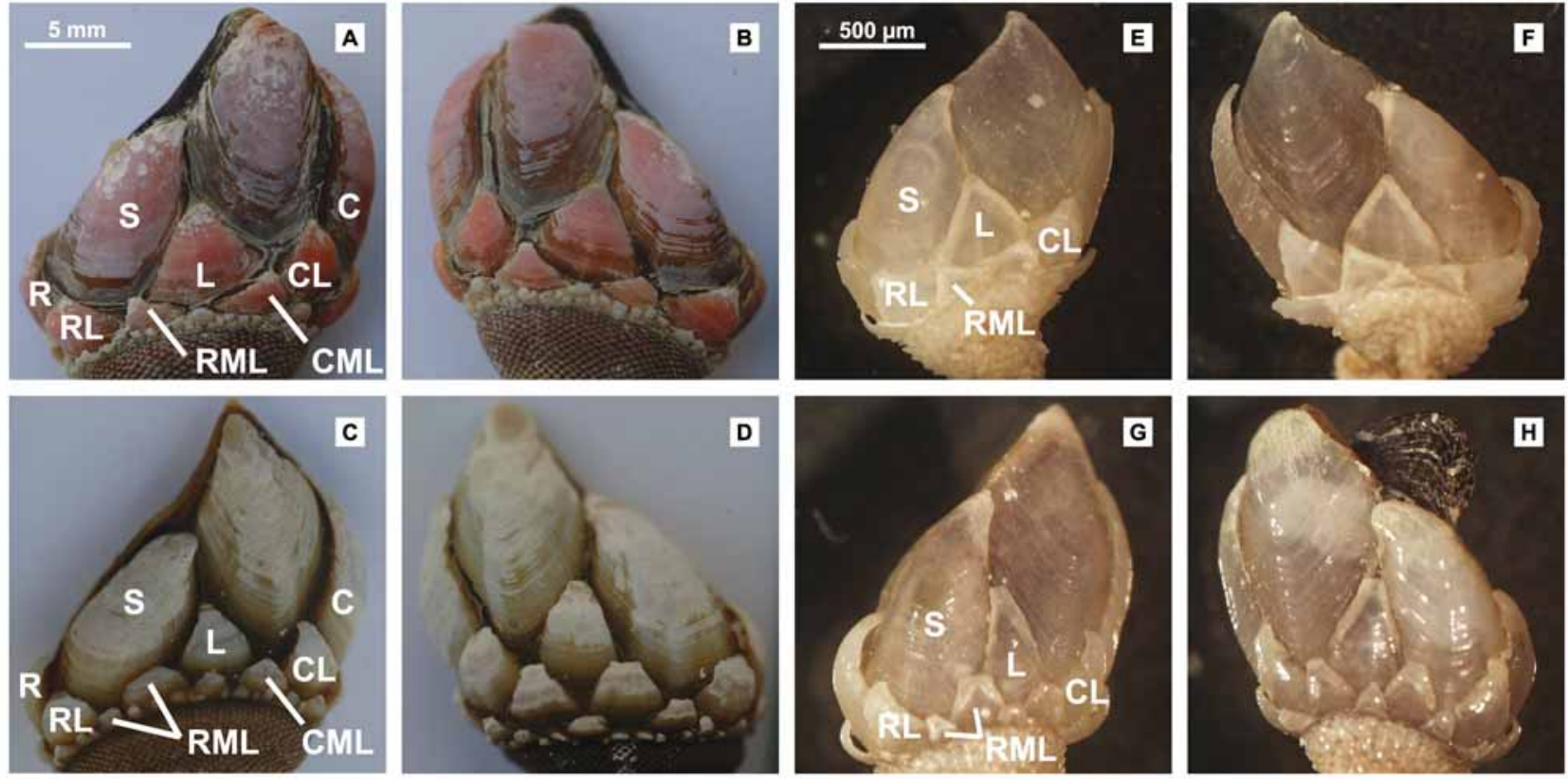

FIGURE 2. Capitular plates of Pollicipes caboverdensis sp. nov. (upper row) and Pollicipes pollicipes (lower row). Scale bar on image A is the same for images B, C and D. Scale bar on image E is the same for images F, G and H. Views of the right side (images A, C, E, G) and left side (images B, D, F, H). Plates: R-rostrum; C—carina; L-median latus; $\mathrm{S} \_$scutum; RL—rostrolatus; $\mathrm{CL} —$ carinolatus; $\mathrm{RML} —$ rostral median latus; $\mathrm{CML} —$ carinal median latus.

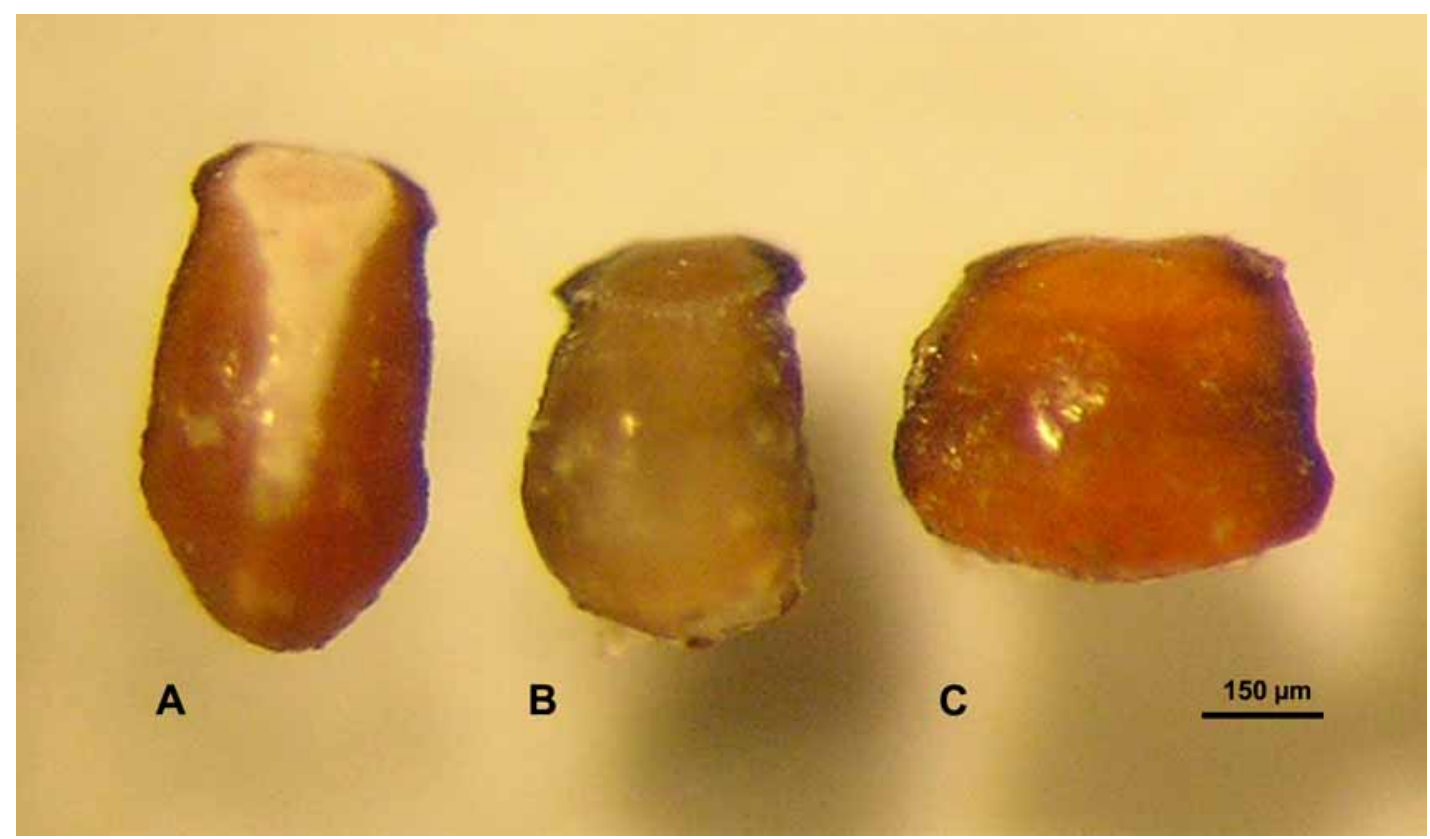

FIGURE 3. Scales of the peduncle of Pollicipes elegans (A), Pollicipes pollicipes (B), and Pollicipes caboverdensis $\mathbf{s p .}$ nov. (C). 

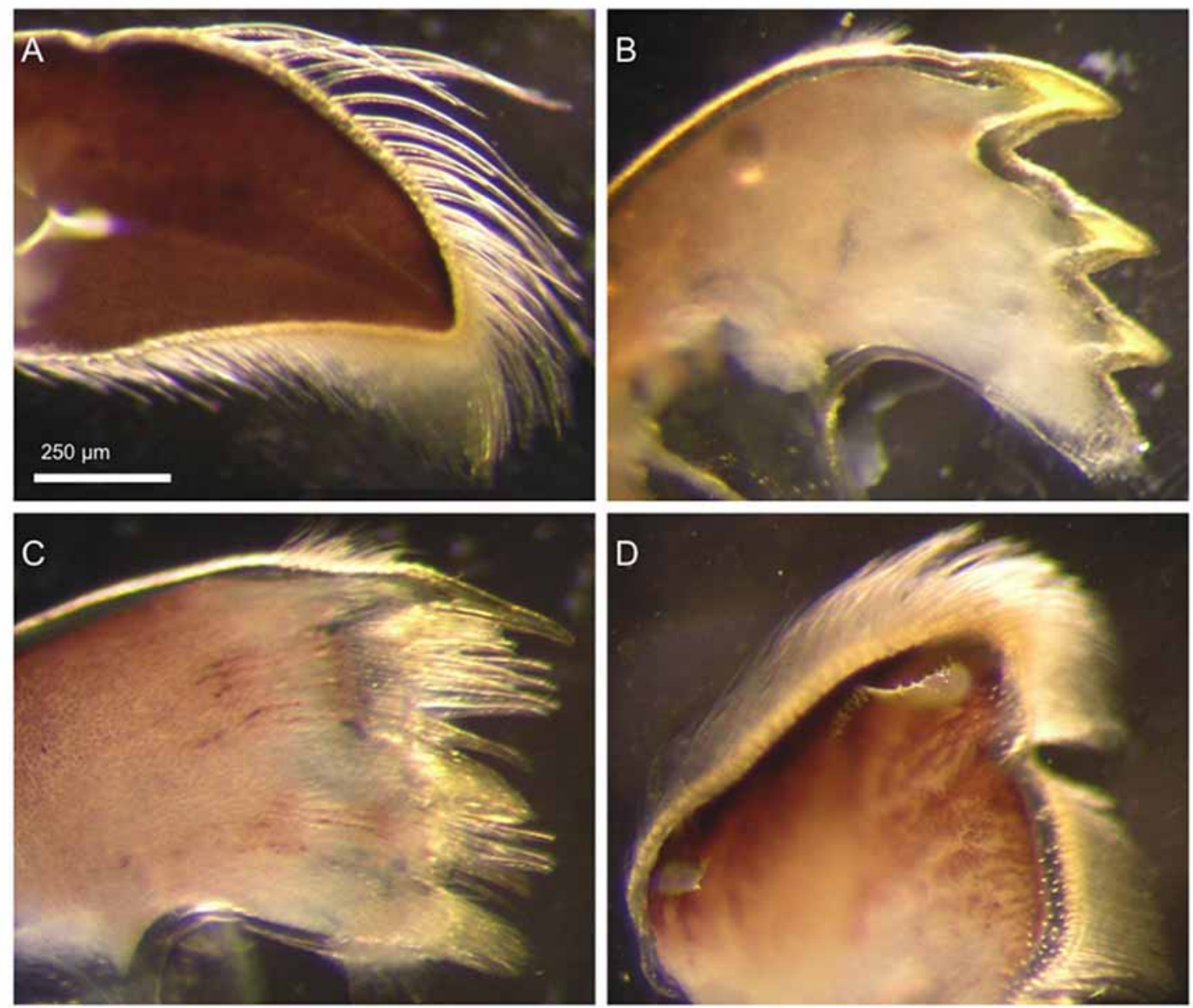

FIGURE 4. Mouth parts (A-mandibular palp; B-mandible; $\mathrm{C}$-maxillule; D-maxilla) of Pollicipes caboverdensis sp. nov. from the right side. Scale bar on image A is the same for images B, C and D.
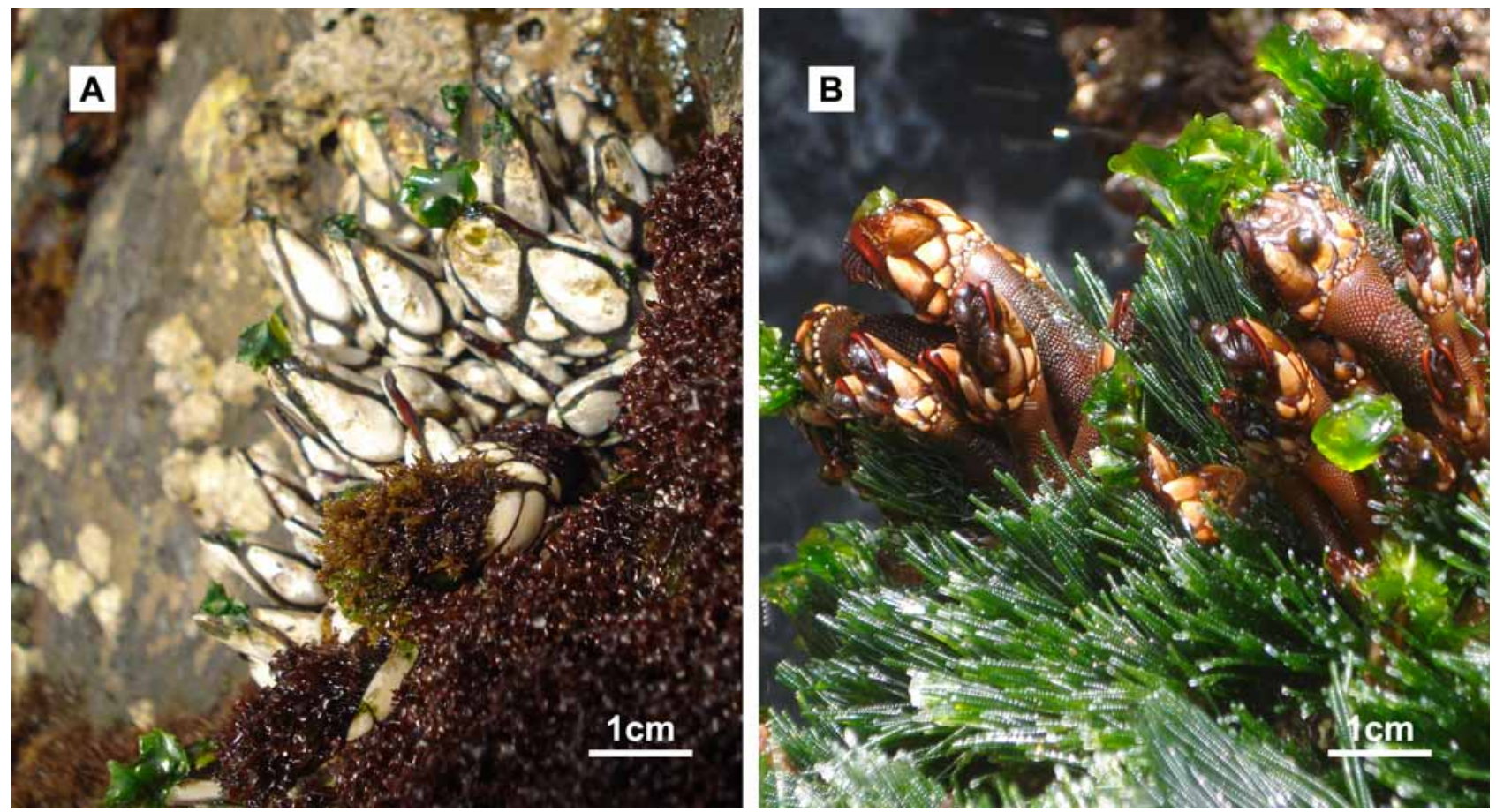

FIGURE 5. A) Pollicipes pollicipes, Dakar, Senegal; B) Pollicipes caboverdensis sp. nov., Santiago, Cape Verde. 


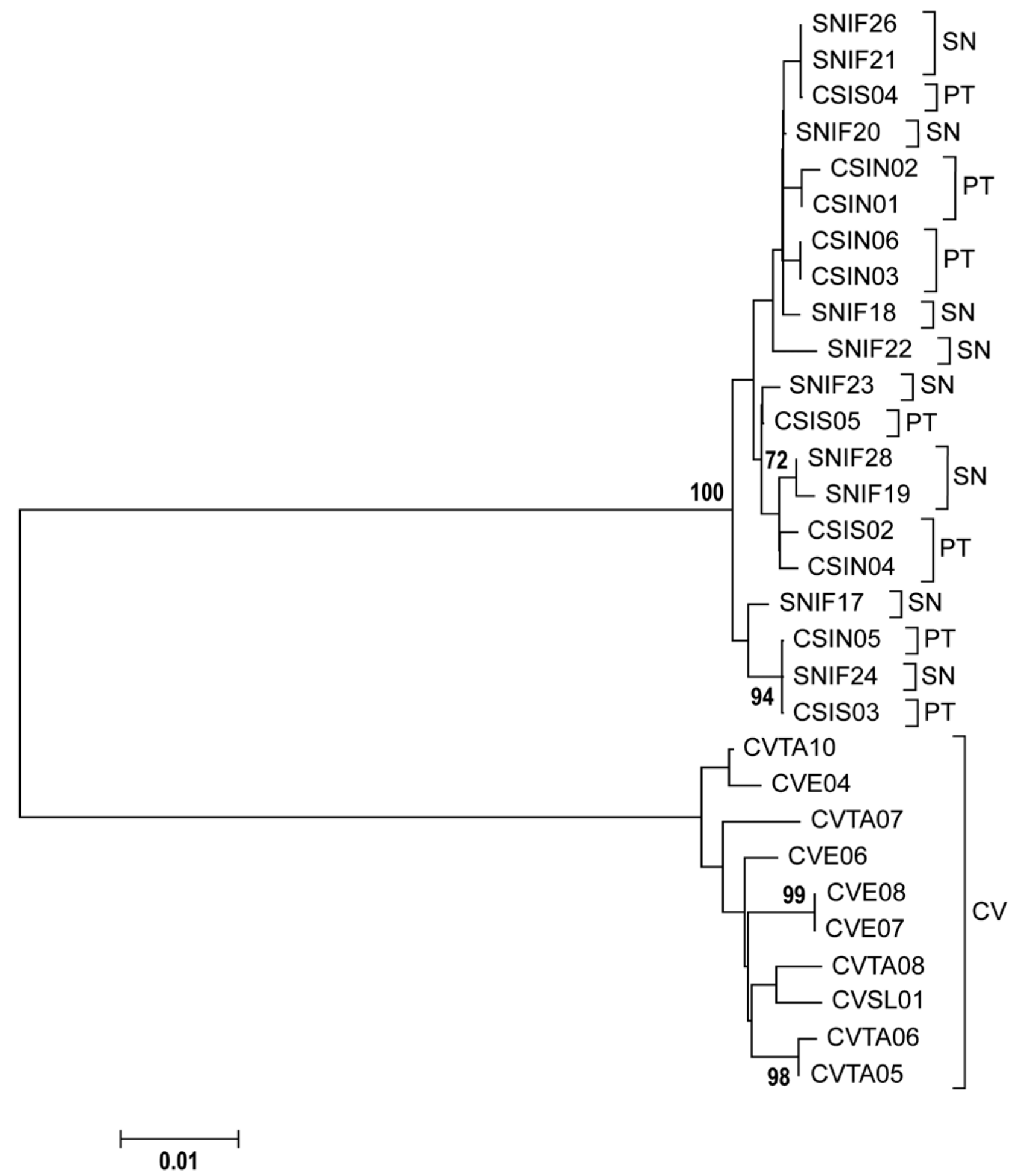

FIGURE 6. Unrooted Neighbor-Joining tree based on mitochondrial cytochrome c oxidase 1 (CO1) nucleotide distances (p-distance) for populations of Pollicipes spp. from each region $(\mathrm{n}=10)(\mathrm{PT}-\mathrm{Portugal}$; SN-Senegal; CV-Cape Verde). Bootstrap support (10000 replicates) for each clade is indicated below nodes for values $>70 \%$.

TABLE 1. Number of segments in each ramus of each pair of cirri of the holotype (right side/left side).

\begin{tabular}{lllllll}
\hline Cirrus & I & II & III & IV & V & VI \\
\hline Anterior ramus & $11 / 11$ & $14 / 15$ & $18 / 18$ & $18 / 18$ & $19 /$ broken & $19 / 21$ \\
Posterior ramus & $9 / 9$ & $16 / 16$ & $18 / 19$ & $20 / 20$ & $20 / 20$ & $21 / 19$ \\
\hline
\end{tabular}


TABLE 2. Pairwise genetic distances (p-distance) of the CO1 gene for populations of Pollicipes spp. (PT-Portugal; $\mathrm{SN}$-Senegal; $\mathrm{CV}$-Cape Verde).

\begin{tabular}{llll}
\hline & PT & SN & CV \\
\hline PT & 0.007 & & \\
SN & 0.007 & 0.007 & \\
CV & 0.133 & 0.132 & 0.010 \\
\hline
\end{tabular}

Caudal appendages subcylindrical, acute, equal to or just exceeding length of lower segment of pedicel of CVI; five to six segments; row of short spines around upper margin of each segment, short tuft of setae apically.

Penis segmented, cylindrical, tuft of fine setae apically.

Distribution. Pollicipes caboverdensis sp. nov. is endemic to the Cape Verde Archipelago and can be found on the north-western, intertidal rocky shores of several islands: Santiago, Sal and São Vicente (observed by authors), Boavista (Quinteiro et al. 2007).

Etymology. Named caboverdensis from the name of the country "Cabo Verde".

\section{Remarks}

Comparisons with other Pollicipes species. Like Pollicipes elegans and P. pollicipes (see Van Syoc 1995), $P$. caboverdensis sp. nov. can also be separated from $P$. polymerus by the presence of a single whorl of capitular plates below the subrostrum (two or more whorls in $P$. polymerus), by the peduncular scales pointing up toward the capitulum (pointing outward in P. polymerus) and by the multi-articulate caudal appendages (uniarticulate caudal appendages in $P$. polymerus).

The reddish-orange colour of the capitulum plates easily separates $P$. caboverdensis $\mathbf{s p}$. nov. from $P$. pollicipes (whitish-grey) (Fig. 2), although this character is not always evident in small individuals (Fig. 2). Additionally, the number of RML plates on the capitulum clearly distinguishes the two species: in $P$. caboverdensis sp. nov. there is one pair while in P. pollicipes there are two pairs (normally one larger and one smaller) (Fig. 2).

In terms of morphology, P. caboverdensis sp. nov. is very similar to P. elegans. No conspicuous differences are found on the capitulum. Nevertheless, the shape of the scales of the peduncle can differentiate the two species: square shaped and about the same width as height in P. caboverdensis sp. nov., narrower, subequal, oval shaped, with a smaller width than height (a characteristic shared with $P$. pollicipes) in $P$. elegans (Fig. 3).

Economic importance. There is no data on the exploitation of the new species at the Cape Verde Islands, but it is sold at local restaurants ( $7.5 \mathrm{~kg}^{-1}$, restaurant at Sal, February 2008, common name "percebes").

Habitat, distribution and abundance of Pollicipes caboverdensis sp. nov. and P. pollicipes at Dakar.

At Sal and Santiago Islands, P. caboverdensis sp. nov. is common in the low/mid shore of exposed shores and we have observed that it was always associated with the green algae Chaetomorpha sp. (Fig. 5). Compared to $P$. pollicipes, the attachment strength to the substratum of $P$. caboverdensis $\mathbf{s p}$. nov. is much weaker and it is easy to collect an entire individual by hand.

At its southern limit (Dakar, Senegal) P. pollicipes was common in front of the IFAN (Fig. 6), occasional at Yoff (a few groups restricted to fissures) and rare at Cap Manuel (2 individuals observed after searching 15 minutes). At IFAN, it was found in the low/mid shore among calcareous turfs and crusts, Caulacanthus sp. and Ulva sp (Fig. 5). In the middle of its geographical distribution (Portugal), P. pollicipes is abundant in the low/mid shore among calcareous turfs and crusts, and Mytilus galloprovincialis (Cruz 2000). 


\section{Molecular analyses.}

Two distinct clusters of individuals with high bootstrap support (100\%) were identified based on CO1 genetic distances (Fig. 6). The first cluster consisted of individuals from Senegal and Portugal and the second cluster consisted of individuals from Cape Verde. The genetic distance between populations from Senegal and Cape Verde was $13.1 \%$, and between Portugal and Cape Verde was $13.2 \%$, while between Senegal and Portugal it was less than $1 \%$, as within Portugal and within Senegal (Table 1). The genetic distance within the Cape Verde group was $1 \%$ (Table 1 ).

Although the delineation of species based solely on mtDNA genetic distance data can be controversial (Galtier et al. 2009), the order of magnitude for sequence divergence within and among populations obtained in this study leaves no doubts on the identification of populations from Senegal as $P$. pollicipes. Mean sequence divergence of the $\mathrm{CO} 1$ gene found in congeneric species of crustaceans was $17.16 \%$ and in conspecifics was $0.46 \%$ (Costa et al. 2007).

Pollicipes caboverdensis sp. nov. is thus endemic to the Cape Verde Islands. There is no evidence of genetic exchange between this species and $P$. pollicipes through planktonic larval dispersal.

\section{Acknowledgments}

The authors wish to thank Youssouph Diatta and Moustapha Mbengue from IFAN for support and help in sampling on the coast of Dakar; Celestino, Luisinho and Zeferino from the "Associação dos pescadores e peixeiras do Tarrafal -Areia Branca" for help in sampling at Santiago; Marta Lança for providing samples from São Vicente; João Barbosa and Catarina Ressureição for helping with logistics at Sal and Santiago; Dr. Richard Grosberg and Brenda Cameron for support and assistance in molecular work; Estibaliz Berecibar for help with identifying the green algae associated with Pollicipes caboverdensis sp. nov.; and Manuel Mota and João Castro for help with the photographs. The Fundação para a Ciência e Tecnologia (FCT) supported JNF through a PhD grant (SFRH/BD/16251/2004).

\section{References}

Barnes, M. (1996) Pedunculate cirripedes of the genus Pollicipes. Oceanography and Marine Biology: An Annual Review, 34, 303-394.

Buckeridge, J.S. \& Newman, W.A. (2006) A revision of the Iblidae and the stalked barnacles (Crustacea: Cirripedia: Thoracica), including new ordinal, familial and generic taxa, and two new species from New Zealand and Tasmanian waters. Zootaxa, 1136, 1-38.

Burmeister, H. (1834) Beiträge zur Naturgeschichte der Rankenfüsser (Cirripedia). G Reimer, Berlin, 68 pp.

Costa, F.O., deWaard, J.R., Boutillier, J., Ratnasingham, S., Dooh, R.T., Hajibabaei, M. \& Hebert, P.D.N. (2007) Biological identifications through DNA barcodes: the case of the Crustacea. Canadian Journal of Fisheries and Aquatic Sciences, 64, 272-295.

Cruz, T. (2000) Biologia e ecologia do percebe Pollicipes pollicipes (Gmelin, 1790) no litoral sudoeste português. $\mathrm{PhD}$ Thesis, Universidade de Évora, 306 pp.

Darwin, C.R. (1852) A monograph on the sub-class Cirripedia, with figures of all the species. The Lepadidae, or, pedunculated cirripedes. Ray Society, London, $400 \mathrm{pp}+$ pls.1-10. (1851)

Darwin, C.R. (1854) A monograph on the sub-class Cirripedia, with figures of all the species. The Balanidae, (or sessile cirripedes); the Verrucidae, etc. etc. etc. Ray Society, London, $684 \mathrm{pp}+$ pls.1-30

Foster, B.A. (1979) The Marine Fauna of New Zealand: Barnacles (Cirripedia: Thoracica). New Zealand Oceanographic Insitute Memoir, 69, 159 pp. + pls. 1-14. (1978)

Galtier, N., Nabholz, B., Glemin, S. \& Hurst, G.D.D. (2009) Mitochondrial DNA as a marker of molecular diversity: a reappraisal. Molecular Ecology, 18, 4541-4550.

Gmelin, J.F. (1790) Vermes, Tomus I, pars VI. In: Gmelin, J. F. (Ed.), Caroli a Linné, Systema naturae per regna tria naturae, secundum classes, ordines, genera, species, cum characteribus differentiis, synonymis, locis. Editio decima tertia, aucta, reformata. G. E. Deer, Leipzig (1788-93), pp. 3021-3910. 
Jacinto, D., Cruz, T., Silva, T. \& Castro, J.J. (2010) The stalked barnacle (Pollicipes pollicipes) harvesting at the Nature Reserve of Berlengas (Portugal): temporal variation and validation of logbook data. ICES Journal of Marine Science, 67, 19-25.

Jennings, L.S. (1915). Pedunculate Cirripedia of New Zealand and neighbouring islands. Transactions and Proceedings of the Royal Society of New Zealand, 47, 285-293.

Leach, W.E. (1817) Distribution systématique de la classe des Cirripèdes. Journal de Physique, de Chimie et d'Histoire Naturelle, 85, 67-69.

Lessard, J., Osborne, J., Lauzier, R., Jamieson, G. \& Harbo, R. (2002) Applying local and scientific knowledge to the establishment of a sustainable fishery: the west coast Vancouver island goose barnacle fishery experience. Putting Fishers' Knowledge to Work, Conference Proceedings, 36-43.

Lesson, R.P. (1831). Zoologie. Mollusques, Annelides et Vers, vol. 2, pt. 1. In Duperrey, L. I. (Ed.) Voyage Autour du Monde Executé par Ordre du Roi, sur la Corvette de Sa Majesté, La Coquille, pendant les années 1822, 1823,1824 et 1825. Zoologie. Paris, Vol. 2(1). pp. 239-471

Linnaeus, C. (1758) Systema naturae per regna tria naturae, secundum classes, ordines, genera, species, cum characteribus differentiis, synonymis, locis. Editio decima, reformata, Tomus I . Laurentii Salvii, Holmiae, 824 pp.

Molares, J. \& Freire, J. (2003) Development and perspectives for community-based management of the goose barnacle (Pollicipes pollicipes) fisheries in Galicia (NW Spain). Fisheries Research, 65(1-3), 485-492.

Newman, W.A. (1987) Evolution of cirripedes and their major groups. In: Southward, A.J. (ed.), Barnacle Biology, Crustacean Issues, 5. A.A. Balkema, Rotterdam, pp. 3-42.

Newman, W.A. \& Killingley, J.S. (1985) The north-east Pacific intertidal barnacle Pollicipes polymerus in India? A biogeographical enigma elucidated by 180 fractionation in barnacle calcite. Journal of Natural History, 19(6), 1191-1196.

Pilsbry, H.A. (1907) The barnacles (Cirripedia) contained in the collections of the U.S. National Museum. Bulletin of the United States National Museum, 60, 1-222.

Pilsbry, H.A. (1916) The sessile barnacles (Cirripedia) contained in the collections of the U.S. National Museum; including a monograph of the American species. Bulletin of the United States National Museum, 93, 1-366.

Quinteiro, J., Rodríguez-Castro, J. \& Rey-Méndez, M. (2007) Population genetic structure of the stalked barnacle Pollicipes pollicipes (Gmelin, 1789) in the northeastern Atlantic: influence of coastal currents and mesoscale hydrographic structures. Marine Biology, 153, 47-60.

Quoy, J.R.E. \& Gaimard, J.P. (1835) Zoologie, Animaux Mollusques, Vol 3, pt. 2. In: J. Tastu (Ed.), Voyage de découvertes de L'Astrolabe, exécuté par l'ordre du Roi, pendant les années 1826-1827-1828-1829, sous le commandement de M. J. Dumont D’Urville. J. Tastu, Paris, pp. 369-954 + plates 1-10

Sourie, R. (1954) Contribution a l'étude écologique des côtes rocheuses du Sénégal. Mémoires de l'Institut Français d'Afrique Noire, 38, Dakar, 345 pp.

Sowerby, G.B. (1833) Pollicipes ruber and polymerus n. sp. Proceedings of the Zoological Society of London, $1,74$.

Stubbings, H.G. (1967) The cirriped fauna of tropical West Africa. Bulletin of the British Museum (Natural History) Zoology, 15(6), 229-319.

Tamura, K., Dudley, J., Nei, M. \& Kumar, S. (2007) MEGA4: Molecular Evolutionary Genetics Analysis (MEGA) software version 4.0. Molecular Biology and Evolution, 24, 1596-1599.

Van Syoc, R.J. (1995) Barnacle mitochondrial DNA: Determining genetic relationships among species of Pollicipes. In: Schram, F. and Høeg, J. (Eds.), New Frontiers in Barnacle Evolution. Crustacean Issues, 10. A. A. Balkema, Rotterdam, pp. 269-296.

Van Syoc, R.J., Fernandes, J.N., Carrison, D.A. \& Grosberg, R.K. (2010) Molecular phylogenetics and biogeography of Pollicipes (Crustacea: Cirripedia), a Tethyan relict. Journal of Experimental Marine Biology and Ecology. doi:10.1016/j.jembe.2010.04.024 